
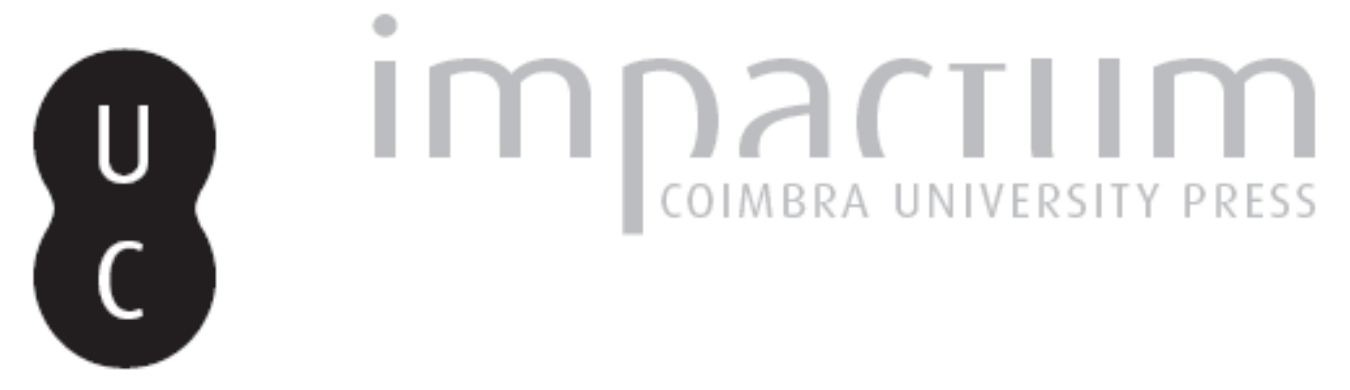

\title{
Santo Tomás, o Tomismo e o Direito
}

Autor(es): $\quad$ Silveira, Carlos Frederico Gurgel Calvet da

Publicado por: Universidade Católica de Petrópolis

URL persistente:

URI:http://hdl.handle.net/10316.2/33789

DOI:

DOI:http://dx.doi.org/10.14195/2175-0947_3-1_1

Accessed : $\quad$ 26-Apr-2023 11:37:45

A navegação consulta e descarregamento dos títulos inseridos nas Bibliotecas Digitais UC Digitalis, UC Pombalina e UC Impactum, pressupõem a aceitação plena e sem reservas dos Termos e Condições de Uso destas Bibliotecas Digitais, disponíveis em https://digitalis.uc.pt/pt-pt/termos.

Conforme exposto nos referidos Termos e Condições de Uso, o descarregamento de títulos de acesso restrito requer uma licença válida de autorização devendo o utilizador aceder ao(s) documento(s) a partir de um endereço de IP da instituição detentora da supramencionada licença.

Ao utilizador é apenas permitido o descarregamento para uso pessoal, pelo que o emprego do(s) título(s) descarregado(s) para outro fim, designadamente comercial, carece de autorização do respetivo autor ou editor da obra.

Na medida em que todas as obras da UC Digitalis se encontram protegidas pelo Código do Direito de Autor e Direitos Conexos e demais legislação aplicável, toda a cópia, parcial ou total, deste documento, nos casos em que é legalmente admitida, deverá conter ou fazer-se acompanhar por este aviso.

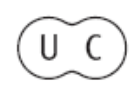



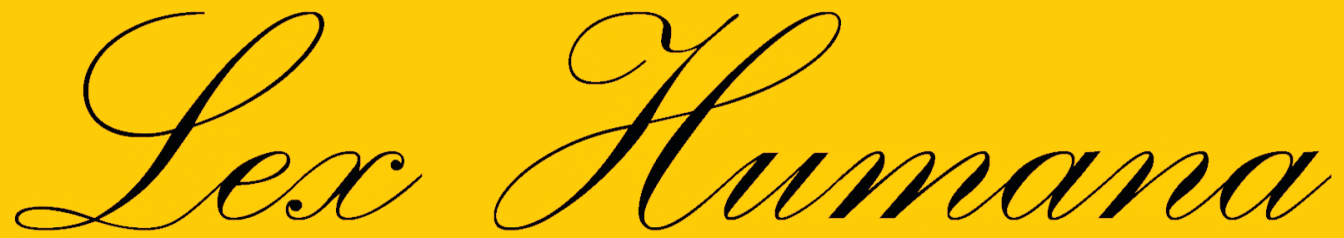

Revista do Programa de Pós-Graduação em Direito da UCP

ISSN(e) 2175-0947

Universidade Católica de Petrópolis Rua Benjamin Constant, 213 - Petrópolis - Centro CEP 25610-130

Tel: (24) 2244-4000 E-mail: lexhumana@ucp.br 


\title{
SANTO TOMÁS, O TOMISMO E O DIREITO ${ }^{1}$
}

\author{
Carlos Frederico Gurgel Calvet da Silveira ${ }^{2}$
}

Resumo: Santo Tomás recebeu de Aristóteles a concepção da excelência da política e, ao comentar a obra de Aristóteles, chama esse saber de ciência arquitetônica. Por outro lado, dentro de uma concepção que se tornará determinante na história do Ocidente até Maquiavel, Tomás subordina a política e o direito à ética. Nada disso seria possível se estas ciências, por sua vez, não estivessem fundamentadas numa metafísica sólida. De que metafísica se trata? É importante abordar, mesmo que brevemente, essa noção e as noçôes principais da metafísica tomista, que chamamos de tomismo essencial, para que se possa entender sua teoria sobre a justiça. Assim como todo o pensamento de Santo Tomás, esta teoria sofreu importantes transformaçóes em sua história, marcadas, sobretudo, por um desvio da metafísica do ser. A recuperação da sua metafísica original permite compreender conceitos como o de lei e de direito natural na dinâmica da participaçáo do ser, assim como entender a justiça como uma virtude ascendente conexa a outras virtudes, sem as quais náo pode ser realizada.

Palavras-chave: Tomás de Aquino; metafísica; justiça; lei natural.

\begin{abstract}
St. Thomas Aquinas received from Aristotle the conception of the excellence of Politics, and commenting on the work of Aristotle, he calls this knowledge architectural science. On the other hand, in a conception that will become crucial in the history of the West to Machiavelli, Thomas submits Law and Politics to Ethics. None of this would be possible if these sciences, in turn, were not grounded in a solid metaphysical. What is metaphysics? It is important to address, albeit briefly, this notion and the main notions of Thomistic metaphysics, which we call essential Thomism, so you can understand his theory of justice. Just like the thought of St. Thomas, this theory has undergone significant transformations in its history, marked mainly by a deviation from the metaphysics of being. The recovery of its original metaphysical allows us to understand the concepts of law and natural right in the dynamics of participation of being, as well as understanding of justice as a virtue ascending related to other virtues, without which it cannot be performed.
\end{abstract}

Keywords: Thomas Aquinas; metaphysics; justice; natural law.

\footnotetext{
${ }^{1}$ Artigo recebido em 02/07/2011 e aprovado para publicação pelo Conselho Editorial em 28/07/2011. Artigo originalmente elaborado por ocasião da conferência proferida na Assembleia Geral Ordinária da União dos Juristas Católicos, RJ, aos 22 de junho de 2011.

${ }^{2}$ Doutor em Filosofia Pontificia Università San Tommaso (Roma). Professor adjunto da Universidade Católica de Petrópolis. Currículo Lattes: http://lattes.cnpq.br/4874832664252533. E-mail: carlos.silveira@ucp.br.
} 
Introdução

No famoso proêmio da primeira da segunda parte da Suma Teológica, o Doutor Angélico, depois de aprofundar na parte precedente ${ }^{3}$ o sentido do homem enquanto imago Dei, retoma sua doutrina nos seguintes termos: "O homem é considerado como feito à imagem de Deus, exprimindo a imagem, como diz Damasceno, a inteligência, o livre arbitrio e o poder sobre si mesmo." ${ }^{4}$

Considerando que a obra do homem manifesta o exercício de seu pensamento e de sua liberdade, emergem aqui de modo especial a política e o direito. Santo Tomás recebeu de Aristóteles a concepção da excelência da política, que ele, ao comentar a mais famosa obra do Estagirita sobre o assunto, chama de ciência arquitetônica 5 . Por outro lado, dentro de uma concepção que se tornará determinante na história do Ocidente até Maquiavel, Tomás subordina a política e o direito à ética.

Nada disso seria possível se esses saberes, por sua vez não estivessem fundamentados numa metafísica sólida. De que metafísica se trata? É importante abordar, mesmo que brevemente essa noção e as noçóes principais da metafísica tomista, que chamamos de tomismo essencial. E que é o tomismo essencial?

\section{Tomás essencial}

Para descobrir isso, dever-se voltar à origem, à fonte, que é o sentido do pensamento de Santo Tomás. Portanto, alguns esclarecimentos metodológicos. Esta não é, pois, uma investigação sobre o tomismo de escola, mas, sim, sobre o próprio Tomás. Também não importa inicialmente o pensamento de Santo Tomás na sua elaboração teórica em suas múltiplas teses. O que importa aqui é entrever o ponto de partida do seu pensamento. Um ponto de partida que dê sentido a toda a sua elaboraçáo teórica e, por conseqüência, nos mostre a fonte da sua vitalidade e sua criatividade.

\footnotetext{
${ }^{3}$ De modo explícito na questâo 93.

${ }^{4}$ TOMÁS DE AQUINO. Summa Theologiae, I-II, proemium: "Quia, sicut Damascenus dicit, homo factus ad imaginem Dei dicitur, secundum quod per imaginem significatur intellectuale et arbitrio liberum et per se potestativum; postquam praedictum est de exemplari, scilicet de Deo, et de his quae processerunt ex divina potestate secundum eius voluntatem; restat ut consideremus de eius imagine, idest de homine, secundum quod et ipse est suorum operum principium, quasi liberum arbitrium habens et suorum operum potestatem."

5 TOMÁS DE AQUINO. In libros politicorum expositio: "Sicut philosophus docet in secundo physicorum, ars imitatur naturam. Cuius ratio est, quia sicut se habent principia adinvicem, ita proportionabiliter se habent operationes et effectus. Principium autem eorum quae secundum artem fiunt est intellectus humanus, qui secundum similitudinem quamdam derivatur ab intellectu divino, qui est principium rerum naturalium. Unde necesse est, quod et operationes artis imitentur operationes naturae (...). Si igitur principalior scientia est quae est de nobiliori et perfectiori, necesse est politicam inter omnes scientias practicas esse principaliorem et architectonicam omnium aliarum, utpote considerans ultimum et perfectum bonum in rebus humanis."
} 
Que é o tomismo essencial? É o pensamento perene de Santo Tomás que se caracteriza pela descoberta do ser como ato intensivo do ente. Isso indica uma permanência que é também uma continuidade. Continuidade com a natureza mesma da filosofia que teve início na Grécia antiga e está interessada no problema fundamental da reflexão filosófica: o sentido do ser. Em outras palavras: o tomismo essencial é aqueles que se insere na esteira da filosofia essencial, que é a filosofia no seu sentido próprio, ou seja, aquela que se desenvolve quando um pensador se volta ao problema do ser em suas múltiplas manifestaçôes.

O interesse investigativo humano brota, como bem se sabe, do estupor, da admiraçáo diante de alguma manifestação do ser, chamada de problema ou de mistério. Essa admiração está presente em toda atividade contemplativa. Vejamos alguns testemunhos que nos chegam da teologia e da filosofia: "que maravilha quando me disseram: vamos à casa do Senhor!”

Não há filosofia se o filósofo não teve em algum momento de sua vida essa vitalidade teológica. Ao contrário, aquele que se dedica à teologia ou à filosofia pode até chegar a exprimir com correção os conceitos que o interessam, mas ele não é mais mediador dessas verdades, é um mero repetidor e, frequentemente, alguém que se afasta dessa tradição viva, caindo no que se pode chamar, depois de Heidegger, de esquecimento do ser.

O esquecimento do ser não é apenas um tema técnico da metafísica contemporânea, ele sintetiza o afastamento do indivíduo dessa experiência de autenticidade que é o estupor. A pretensão de tudo poder explicar e pôr em conceitos, cada dia mais especializados, elimina em sua raiz a possibilidade dessa experiência. O próprio tomismo de escola, em sua longa história, foi expressão desse esvaziamento, antes mesmo do predomínio do cientificismo contemporâneo. Todos sofrem do mesmo mal.

Com o tomismo essencial, atingimos o fundamento da filosofia de Santo Tomás, que é a fonte de sentido de todo o seu pensamento. Sua perenidade reside aí. O rigor com o qual ele desenvolve seus argumentos remete ao modus philosophandi escolástico medieval, nem sempre em consonância com as instâncias filosóficas modernas e contemporâneas.

\subsection{A estrutura metafísica do ente}

Podemos vislumbrar uma estrutura metafísica geral do ente a partir das grandes contribuiçóes filosóficas de Parmênides até Tomás de Aquino. Este aperfeiçoou alguns princípios aristotélicos a partir de uma nova identificação do ser de Parmênides. 
Qual teria sido a contribuição genuína de Tomás para a história do pensamento ocidental? Seguindo Aristóteles, Tomás desenvolve sua filosofia através dos conceitos de ato e potência; matériaprima e forma; substância e acidente; e de essência. Ora, todos esses conceitos pertencem a Aristóteles, de modo que a novidade de Tomás está em relacionar esses conceitos com outro: o conceito de ser. Para Aristóteles, forma, essência, acidentes são atos, isto é, perfeição. Tomás, entretanto, descobriu que, embora esses conceitos exprimam perfeição, a perfeição fundamental é o ser (esse), sem o qual as outras não seriam.

Em metafísica, as teses partem das composições fundamentais dos entes finitos, quais sejam: a composição de ato e potência, que é o fundamento de qualquer composição (pois o composto sempre supóe potência); a composiçáo essencial de matéria prima e forma substancial; a composição de ser (esse) e essência; e a de substância e acidentes.

\subsection{O ser}

Desde os seus primórdios, a filosofia foi entendida como um saber universal que procurava descobrir o elemento primário da realidade. Nesse contexto, o tema do ser surge com Parmênides e, com Platáo, ganha um sentido técnico e verdadeiramente metafísico. Porém, pode-se dizer que, em certa medida, é Aristóteles que devolve ao ser seu primado na investigação filosófica, ao considerar a metafísica como a ciência do ente enquanto ente. A inovadora abordagem de Aristóteles a respeito do tema do uno e do múltiplo, que também ocupou um lugar central na especulação metafísica desde as origens do filosofar, abre novos horizontes para o tema do ser. Para o Estagirita, uno, múltiplo e ser só se explicam com a distinção entre ato e potência. $\mathrm{O}$ ato - enérgeia, enteléqueia - contrapóe-se à potência - dýnamis como o perfeito e acabado, a realização da forma, à capacidade real não realizada. Por isso mesmo, o ser tem muitos significados, conforme a memorável asserção de Aristóteles no início do livro $\mathrm{Z}$ de sua Metafisica ${ }^{6}$.

O processo do desenvolvimento teórico aristotélico, entretanto, conduzirá o Estagirita a uma formalização do conceito do ser, e é aqui que se pode notar sua diferença com interpretação tomista. O descobrimento do ser como ato, esse ut actus, em Santo Tomás proporciona ao tomismo uma situação privilegiada no pensamento contemporâneo. Confirma-o Cornelio Fabro: "Concretamente, Santo Tomás supera a relação (ou tensão) aristotélica entre ato e potência, de modo que o ato não é intrinsecamente informante, como para Aristóteles, mas é constitutivo de si mesmo, de sua emergência

${ }^{6}$ ARISTÓTELES. Metafisica, 1028a , 6.

http://seer.ucp.br/seer/index.php/LexHumanalindex 
sobre qualquer potência ${ }^{7 ”}$. A tensão entre transcendência e imanência se explica e resolve no ato de ser fundante do ens, também no conhecimento, que remete necessariamente ao Ipsum Esse Subsistens, através da participação.

Em definitiva, o ser constitui o ato primeiro e mais íntimo do ente, que, ab intra, confere ao sujeito toda sua perfeição, pois qualquer ato ou perfeição antes deve ser, isto é, há de ter previamente o ato de ser, do contrário, nada seria.

Em contrapartida, os entes, porque menos perfeitos do que o ser em si, possuem menos ser, têm menor grau de participação no ser. Historicamente, tal concepçáo tomista do ser cedeu espaço a um entendimento abstrato do ser, como o ser comum, que é, sobretudo, o ser entendido extensivamente, com o mínimo de conteúdo. Esta teoria, presente no final do pensamento medieval, formula-se de modo explícito no racionalismo. Com distintos matizes, filósofos como Suárez, Leibniz, Wolff, Kant, etc., passaram a entender o ser não como ato, senáo como efetividade (do esse ut actus ao esse actu).

Um dos inconvenientes principais desta postura é que o ente se assimila ao pensamento, já que tal noção indeterminadíssima do ser só existe na inteligência humana, como fruto de uma abstração lógica. Não se trata mais do ser real, senão do ser pensado, do ser possível, pois a "possibilidade" é o caráter "não-contraditório" de uma noção, isto é, a "possibilidade de que algo seja pensado ou concebido".

Por conseguinte, assistimos à substituiçáo do conceito de ser pelo de existir. Contudo, para o tomismo, existir designa somente aspecto mais exterior do ser, como uma conseqüência sua: porque o ente tem ser, está aí realmente, fora do nada, e existe. Interpretar ser como existência, é um resultado lógico da posiçấo indicada anteriormente, que reduz o ente à essência possível, à margem do ato de ser. Formam-se assim dois mundos: por um lado, a esfera ideal das essências abstratas ou do pensamento puro; por outro lado, o mundo dos fatos, da existência fática. Este segundo não é mais do que uma reprodução do primeiro: como dizia Kant, o conceito de cem táleres reais em nada difere do conceito de cem táleres simplesmente possíveis. Contudo, a perenidade da filosofia de Santo Tomás deve-se a que o ser, por reunir de modo cabal as características de ato, pode subsistir independentemente de toda potência. O ser é o ato de todos os demais atos do ente, pois atualiza qualquer outra perfeição, fazendo-a ser. Por exemplo, o agir, que é ato segundo, fundamenta-se nas potências operativas - ato primeiro na ordem dos acidentes -, e estas faculdades, com o resto das perfeiçôes acidentais, recebem sua própria

\footnotetext{
${ }^{7}$ FABRO, Cornélio. “Santo Tomás de Aquino: ontem, hoje, amanhā”, in: Hora Presente. p. 252. 
atualidade da forma substancial, que é o ato primeiro da essência. Destarte, toda a perfeição da essência deriva do ser, que é por isso, com propriedade, ato último e ato de todos os atos do ente.

$\mathrm{O}$ ato de ser é então atingido por um percurso que revela, por um lado, o processo histórico do aprofundamento metafísico ocidental, e, por outro, a própria estrutura metafísica dos entes, de modo que de ato em ato, ou seja, do ato acidental ao substancial, se atinge o esse, ato de todos os atos. É o que se depreende do texto que se segue:

O próprio ser é o que há de mais perfeito em todas as coisas, é comparado a todas como seu ato. Nada, portanto, tem atualidade a não ser enquanto é, donde o próprio ser é a atualidade de todas as coisas e até mesmo das próprias formas. Donde não é comparado às outras coisas como o recipiente ao recebido, mas antes como o recebido ao recipiente. Quando, pois, digo o ser do homem ou do cavalo ou de qualquer outra coisa, o próprio ser é considerado como formal e recebido e não como aquilo a que compete o ser ${ }^{8}$.

\section{O rompimento com Santo Tomás}

Se admitirmos que a visão de Agostinho na Cidade de Deus é, em certa medida, um eclipse da política grega, e que a de Santo Tomás, uma recuperação desse ideal, ao menos no que diz respeito à origem natural do Estado e às teses daí decorrentes, assistimos no início do século XIV, com Egídio Romano, a um novo eclipse.

Sem dúvida, a partir de Santo Tomás, e com o auxílio da filosofia de Aristóteles, a ordem do mundo já estava assegurada, uma vez que a sociedade política é exigência da natureza humana e existiria mesmo que o homem não tivesse pecado. Ora, o agostinismo favorecia a interpretação de que o Estado era fruto de pacto, por causa do pecado? . Se o homem não tivesse pecado, o Estado talvez não tivesse sentido. Egídio, como tomista ambíguo, assumiu claramente essa tendência do agostinismo. Já que todo poder vem de Deus, a questão é saber como ele procede de Deus, ou seja, diretamente ou indiretamente. $\mathrm{Na}$ concepção de Egídio, seguindo a lógica dessas premissas, a autoridade religiosa tem dignidade maior do que a civil, e, portanto, o poder vem de Deus de modo ordenado, sendo os poderes inferiores instituídos pelos superiores. Eis uma questão crucial para a aplicação da doutrina da lei natural no final da Idade Média.

\footnotetext{
${ }^{8}$ TOMÁS DE AQUINO. Suma Teológica I, q. 4, a. 1, ad 3m: Ipsum esse est perfectissimum omnium, comparatur enim ad omnia ut actus. Nibil enim habet actualitatem, nisi inquantum est, unde ipsum esse est actualitas omnium rerum, et etiam ipsarum formarum. Unde non comparatur ad alia sicut recipiens ad receptum, sed magis sicut receptum ad recipiens. Cum enim dico esse hominis, vel equi, vel cuiuscumque alterius, ipsum esse consideratur ut formale et receptum, non autem ut illud cui competit esse. Tradução acima própria do autor.

${ }^{9}$ AGOSTINHO DE HIPONA, A Cidade de Deus, XIV, 28: Eis aqui a famosa passagem em que Agostinho esclarece as prerrogativas das duas cidades: "Dois amores geraram duas cidades: a terrena, o amor de si até a indiferença de Deus; e a celeste, o amor a Deus até a indiferença em relação a si..."
} 
Nesses moldes, o pontífice é o ápice do poder: a amplidão do poder eclesiástico culmina e resume-se em um só homem, no qual se encontra toda soberania. $\mathrm{O}$ espiritual julga e não é julgado por ninguém. É o absolutismo do poder eclesiástico ou chamada "plenitudo potestatis".

Se a "plenitudo potestatis" era doutrina já conhecida, a origem do poder através da sacramentalização da ordem social é, em parte, trabalho de Egídio. Assim, o batismo torna-se novamente o fundamento da ordem social, de modo que o pecador perde domínio, poderíamos dizer direitos, quando se afasta da vida eclesial. Teórico do absolutismo, Egídio acabou tendo seu pensamento explicado de modo que seguramente não imaginou. É claramente um desvirtuamento do ideal tomista e, em certa medida, uma volta à tendência agostinista, aliás já presente na própria metafísica de Egídio.

É conhecida a tese que revela que Egídio traiu a concepção original do ser de Santo Tomás, gerando graves conseqüências na interpretação do "esse" tomista, conseqüências que só serão esclarecidas no século XX. Poderíamos resumir essa relação de sua metafísica com sua política do seguinte modo: a política de Egídio é o sintoma mais agudo do abandono do ser de Santo Tomás, entendido de modo intensivo no Doutor Angélico e como ser extensivo ou "esse commune" em Egídio. Ora, o ser comum é abstrato, o que, na verdade, provoca o renascimento do formalismo, do essencialismo, base das posturas totalitárias.

Uma reação moderada a Egídio encontra-se em Jean Quidort. No De potestate regia et papali, o teólogo francês defende a separação entre o poder político e o religioso e reivindica o caráter fundamentalmente moral da autoridade eclesiástica, enquanto atribui o poder coercitivo à autoridade civil. Mais fiel a Santo Tomás, insiste no aspecto natural do Estado, mas também fala de pacto, porque a formação do Estado não é automática, passa por estágios, e o pacto é justamente isso e não é excludente, ou seja, não contradiz a origem natural do Estado. Quidort, dentro da lógica tomista e seguindo seus próprios caminhos, insiste mais no aspecto individualista do que fizera seu mestre para a formação da sociedade, e defende o fim autônomo do próprio Estado. Identificando o político com o natural, o governo civil com a ordem da natureza - e o eclesiástico com a da graça - e alargando mais do que o mestre o espaço para a ordem natural, Quidort encontra a justificativa para a relativização do governo civil. O poder da Igreja é moral, o do Estado é coercitivo.

Ao contrário, Marsílio de Pádua acentua as diferenças em seu Defensor Pacis. Essa obra pode ser considerada a base sobre a qual se edificará o Estado moderno, isto é, o princípio de soberania, que se realiza através de dois elementos ligados ao Estado, a saber, a autonomia do poder político civil e 
monismo estatal, ou seja, a atribuição do poder a um só governo, que deve ser civil. Apoiando-se na Política de Aristóteles, Marsílio combate a pretensão papal à "plenitudo potestatis”.

Por outro lado, em oposição às reivindicaçóes desmedidas do poder temporal e do poder eclesiástico, representadas por Marsílio de Pádua, de um lado, e pelos curialistas, de outro, Guilherme de Ockham adere, em sua política, a uma corrente moderada e até ortodoxa. Ambos os poderes, imperial e papal, são autônomos, mas os dois devem colaborar para o bem comum. Do Brevilóquio:

Não se pode provar que o império provém do papa pelas palavras da Escritura que exaltam a eminência do poder e da dignidade de Cristo. Em primeiro lugar, cabe demonstrar que náo se pode provar que o império provém do papa e que o imperador seja vassalo do papa, tomando-se para tanto aquelas palavras da Sagrada Escritura que exaltam a eminência do poder concedido a Cristo por Deus (...).

Deve-se dizer, pois, que embora o papa seja o vigário de Cristo, contudo, não lhe foi concedido todo o poder de Cristo, nem segundo a divindade, nem segundo a humanidade, como herética e adulatoriamente confabulam alguns papólatras. Do poder do papa, como já foi visto, excetuam-se os direitos e liberdade concedidos aos outros por Deus e pela natureza, e por isso, além daquilo que por necessidade deve ser feito e que é ordenado pela lei divina e o direito natural, não pode oprimir com graves e onerosas ordenaçôes, estatutos, leis ou preceitos, os inocentes que a tal se opóem. E se o fizer, deve ser convencido que está lançando sua foice na seara alheia, e está fazendo o que não compete a seu ofício e, por isso, o que vier a fazer é nulo pelo próprio direito ${ }^{10}$.

Ora, o problema da relação Igreja-Estado, tal como ele aparece no pensamento medieval, envolve a doutrina da lei natural. O que acontece, no processo inevitável de negação dos exageros da disputa sobre o poder religioso sobre o Estado, é o paulatino descrédito da doutrina da lei natural na medida em que esta servia à dialética da fundamentação da superioridade do poder espiritual sobre o temporal. Também neste campo Maritain oferece uma reflexão madura, útil para o tempo contemporâneo. A esse respeito, dá testemunho seu recente comentador, Paul Valadier, justamente no capítulo onde trata da relação Igreja e Estado:

Pode-se deixar de lado as conclusóes práticas tiradas desses princípios e, sobretudo, observar que mesmo permanecendo no quadro de princípios que valiam para "a civilização sacral da Idade Média”, Maritain renova profundamente seus aportes, a ponto de ter sido atacado de infidelidade à tradição, especialmente ao pensamento tomista ${ }^{11}$.

${ }^{10}$ OCKHAM, Guilherme. Brevilóquio sobre o principado tirânico, V, c. III.

11 "On peut laisser de cote les conclusions pratiques tirées de ces principes et surtout obsever que tout en restant dans le cadre des principes qui valaient pour "la civilisation sacral du Moyen Âge", Maritain em renouvelle profondément La portée au point d'avoir étê attaqué pour infidélité à la tradition, notamment à la pensée thomiste”. VALADIER, Paul. Maritain à contre-temps. Paris: Desclée de Brouwer, 2007, p. 132. Tradução do autor. 
Essas disputas, freqüentemente inúteis, geraram a necessidade de novos fundamentos para o direito natural, o que vai desembocar na negação do princípio da lei natural e, mais tarde, do próprio direito natural. E esta é uma terceira investigação, mesmo que breve.

3. O processo histórico de negação da lei natural

Poderíamos dividir a história da filosofia em dois grandes blocos: o pensamento clássico (isto é, antigo e medieval) e o pensamento moderno. O primeiro podemos dizer que foi inaugurado por Platão e pode ser caracterizado de filosofia da transcendência; o segundo encontra em Spinoza o seu modelo: é a filosofia da imanência.

O spinozismo é, pois, uma das fontes do imanentismo. No que concerne à questão do direito, Spinoza insere-se na tradição moderna que afirma o direito natural, mas sua peculiaridade está em assumir tanto o racional quanto o divino na fundamentação do direito graças à identificação da natureza com o próprio Deus. Afirma então Spinoza:

Todos existem por direito supremo da natureza e conseqüentemente cada um faz, pelo direito supremo da natureza, o que decorre da necessidade de sua própria natureza; e assim cada um julga, pelo direito supremo da natureza o que é bom, o que é mau, ou consulta a sua utilidade segundo o seu engenho, se vinga, e se esforça por conservar aquilo que ama, e por destruir aquilo que odeia. Porque se os homens vivessem dirigidos pela razão, cada um possuiria o direito que lhe pertence, sem nenhum prejuízo para outrem ${ }^{12}$.

Esta passagem da Ethica ilustra de modo exemplar a concepção de direito natural que Spinoza defende. Os elementos que compóem a doutrina sintetizada nesse parágrafo podem ser mais bem entendidos por meio de outra passagem, igualmente fundamental, do Tratado Teológico-Político, capítulo XVI, que justamente se intitula Dos fundamentos do Estado, do Direito Natural e Civil de cada individuo e do direito dos Soberanos. Embora o título anuncie outros temas importantes, o cerne da discussão é o direito natural. As teses principais enunciadas no referido capítulo podem ser agrupadas segundo os seguintes elementos: primeiro, a existência é decorrência de um direito supremo da natureza; segundo, o agir segue a necessidade da natureza de cada um; terceiro, o juízo sobre o bem e o mal é relativo à conservação do que interessa ao esforço de autopreservação; quarto, o seguimento da razão é o critério

\footnotetext{
${ }^{12}$ SPINOZA, Baruch. Ética, IV, p. 37, sch 2. GEBHARDT, Carl (org.). Spinoza Opera. Heidelberg: Carl Winter, 1972, v. II: "Existit unusquisque summo naturae jure, \& consequentersummo jure naturae unusquisque ea agit, quae ex suae naturae necessitate sequuntur; atque adeo summo naturae jure unusquisque judicat, quid bonum, quid malum sit, suaeque utilitati ex suo ingenio consulit, seseque vindicat, \& id, quod amat, conservare, \& id, quod odio habet, destruere conatur. Quod si homines ex ductu rationis viverent, potiretur unusquisque hoc suo jure absque ullo alterius damno". 
para o reconhecimento do próprio direito sem prejuízo de terceiros. À guisa de ilustração, valem as seguintes passagens: 'Por direito e instituição da natureza entendo unicamente as regras da natureza de cada indivíduo, regras segundo as quais concebemos qualquer ser como naturalmente determinado a existir e a agir de certa maneira ${ }^{13 "}$. E ainda:

É, com efeito evidente que a natureza, considerada em absoluto, tem direito a tudo o que está em seu poder, isto é, o direito da natureza estende-se até onde se estende a sua potência, pois a potência da natureza é a própria potência de Deus, o qual tem pleno direito a tudo ${ }^{14}$.

A Crítica da Razão Pura, ao inaugurar uma nova era do pensamento ocidental, pôs em cheque de modo especial o estatuto do sujeito cognoscente, ou seja, daquela realidade entendida como o substrato, o sustentáculo das experiências cognoscitivas humanas, sobretudo do sujeito como pólo oposto ao objeto no processo humano de conhecimento.

A concepçáo clássica do sujeito cognoscente tem sua origem no processo de conhecimento analógico da realidade, que, desde os gregos antigos, supôs que tudo aquilo que existe ou existe em si ou em um substrato: ou são substâncias, indivíduos, ou são acidentes. Assim, um cão, enquanto substrato, seria um sujeito com as características da sua espécie acrescido da existência singularizada. Por outro lado, suas características, como cor, tamanho, cheiro etc. seriam acidentes, o que completaria sua individualidade. É bom lembrar que indivíduo é definido como o "sujeito com todas as suas perfeiçôes", o ser, a essência e os acidentes. Esta teorização do substrato ganha sua formulaçáo mais acabada em Aristóteles, de onde nascem as mais importantes teorias do sujeito em geral e dos múltiplos sentidos de sujeito, o gramatical, inclusive. Embora Kant defenda a 'lei natural', o que esse autor pretende indicar com essa expressão está marcado pelo seu criticismo e, por conseguinte, tem valor meramente prático e não especulativo, como se pode depreender da introdução de sua Metafísica dos Costumes. Maritain observa o seguinte a respeito do que se disse:

A Lei Natural ia ser deduzida da assim chamada autonomia da Vontade. É fato que existe uma verdadeira noção de autonomia da razão, a de São Paulo, mas infelizmente o século XVIII a tinha olvidado. Os direitos da pessoa humana iam então ser baseados na pretensão de que o homem não está sujeito a lei alguma senão à de sua própria vontade e liberdade. "Uma pessoa",

\footnotetext{
${ }^{13}$ SPINOZA, Baruch. Tratado Teológico-politico. Lisboa, Imprensa Nacional: 1988, XVI, 189, 12-15. GEBHARDT, Carl (org.). Spinoza Opera. Heidelberg: Carl Winter, 1972, v. III: “Per jus \& institutum naturae nihil aliud intelligo, quam regulas naturae uniuscujusque individui, secundum quas unumquodque naturaliter determinatum concipimus ad certo modo eixstendum \& operandum".

${ }^{14}$ SPINOZA, Baruch. Tratado Teológico-politico. Lisboa, Imprensa Nacional: 1988, I, 189, 17-21. GEBHARDT, Carl (org.). Spinoza Opera. Heidelberg: Carl Winter, 1972, v. III: "Nam certum est naturam absolute consideratam jus summum habere ad omnia, quae potest, hoc est, jus naturae eo usque se extendere, quo usque ejus potentia se extendit; naturae enim potentia ipsa Dei potentia est, qui summum jus ad omnia habet..."
} 
escreveu Kant, "não está sujeita a quaisquer outras leis senão àquelas que prescreve para si mesma, seja só, seja em união com outros homens" 15

Em Hegel, o imanentismo spinozista, filtrado pelo pensamento crítico de Kant, tem sua expressão máxima. A experiência da consciência revelará a totalidade da ciência, o seu rigor enquanto sistema. $\mathrm{O}$ percurso fenomenológico da consciência é longo, verdadeiro Calvário, a Sexta-feira Santa, na significativa expressão hegeliana, para se chegar à glória, isto é, à universalidade do conceito, ao pensar como sistema. Assim o ser que depende da consciência perde a sua individualidade na universalidade anuladora do sistema, no seu acabamento, ou seja, no fechar-se sobre si mesmo: eis o saber absoluto.

O espírito prevalece e neste sentido ele se distingue do natural, e então quando se fala de direito natural, se supõe o estado de natureza que é um absurdo ético. No parágrafo terceiro das Liçóes sobre a filosofia do direito, Hegel declara que o direito é positivo em geral: pela forma da vigência em um Estado e quanto ao conteúdo, isto é, tem caráter racional, desenvolvimento histórico, um sistema de aplicação do universal e determinaçóes últimas para a decisão ${ }^{16}$.

Com essas premissas, mas especialmente a partir de Kant e de Hegel, vemos se afirmar a postura negativa em relação ao direito natural, talvez como tentativa para resolver as questôes mais complexas do próprio direito, como a variabilidade da lei. Assim podemos encontrar hoje afirmaçóes como as de Kelsen: "O jurista positivista, quando estabelece a norma fundamental, é guiado pela tendência de reconhecer como Direito objetivo o maior número possível de atos empiricamente conhecidos que devem ter como significado subjetivo atos jurídicos. Estes atos criadores e executores de Direito constituem a chamada realidade histórico-política. Assim, a norma fundamental significa, em certo sentido, a transformação do poder em Direito ${ }^{17 ”}$.

Norberto Bobbio, seguidor de Kelsen, em significativa obra já publicada no Brasil, critica o positivismo distinguindo três modos de considerar o positivismo jurídico: o positivismo como método, como teoria do direito e como ideologia ${ }^{18}$. O filósofo italiano aceita o papel metodológico desse sistema, mas só parcialmente ou de modo muito mitigado a teoria:

Concluindo: dos três aspectos nos quais se pode distinguir o positivismo jurídico, me disponho a acolher totalmente o método; no que diz respeito à teoria, aceitarei o positivismo em sentido amplo e repelirei o positivismo em sentido estrito; no que concerne à ideologia, embora

\footnotetext{
${ }^{15}$ MARITAIN, Jacques. O homem e o Estado, p. 99.

${ }^{16}$ HEGEL, G.W.F. Lineas fundamentales de la filosofía del derecho, p. 39.

${ }^{17}$ KELSEN, Hans. Teoria geral do Direito e do Estado, p. 425.

${ }^{18}$ BOBBIO, Norberto. O positivismo jurídico, p. 234.
} 
seja contrário à versão forte do positivismo ético, sou favorável, em tempos normais, à versão fraca, ou positivismo moderado ${ }^{19}$.

Em suma, o abandono do método realista de Tomás conduziu a filosofia e o direito não somente ao uma perda da orientaçáo conceitual, pois indica a próprio distanciamento da fonte do direito, mas também, como consequência gritante, a confusão e ambiguidade dos termos na justiça. Todos os conceitos até aqui referidos ou foram abandonados ou são empregados em sentido oposto ao original, até mesmo em pareceres e sentenças dos nossos mais altos tribunais.

4. A lei natural no sistema democrático

\subsection{Jacques Maritain e o Estado democrático}

Maritain observara, antes que Bobbio escrevesse as linhas acima, as seguintes consideraçóes que corroboram o que ficou dito até aqui:

Os fundamentos filosóficos dos Direitos do Homem é a Lei Natural. Lamento não podermos encontrar outra palavra! Durante a era racionalista, juristas e filósofos deturparam de tal modo a noção de lei natural, quer para fins conservadores, quer para fins revolucionários, apresentaram-na de maneira tão simplificada e tão arbitrária que é difícil empregar, hoje em dia, o termo, sem despertar a desconfiança e a suspeita em muitos de nossos contemporâneos. Eles deveriam, entretanto, lembrar-se de que a história dos direitos do homem está ligada à história da Lei Natural, e que o descrédito em que, por certo tempo, o positivismo lançou a idéia da Lei Natural, provocou inevitavelmente um descrédito semelhante para a idéia dos direitos do homem ${ }^{20}$.

Pode-se dizer, com Maritain, que a lei natural é a maior garantia do Estado democrático e da concretização dos ideais proclamados na Declaração Universal dos Direitos Humanos.

Em O homem e o Estado, que é obra de 1953, Maritain critica o conceito ilusório de soberania que ele atribui a Jean Bodin e a Thomas Hobbes: passou-se do direito do povo de se governar para o poder de governar. Em lugar de participação, a perda de participação. Defende, então, uma filosofia democrática do poder, que, por ser tal, exige aquilo que decorre da própria natureza humana: a liberdade e a confiança no povo. Essa confiança é o primeiro axioma e preceito da democracia. Insiste ainda que uma democracia supóe um "credo comum" e que o bem comum supóe o reconhecimento dos direitos da pessoa. Finalmente que o bem comum transcende a sociedade política.

${ }^{19}$ ID.IBID., p. 238.

${ }^{20}$ MARITAIN, Jacques. O homem e o Estado, p. 96. 
O axioma da confiança no povo baseia-se no elemento fundamental da lei natural de que o poder emana do povo e está a seu serviço. Toca-se aqui exatamente nos elementos mais importantes da democracia: a liberdade, a soberania e o bem comum. Qualquer totalitarismo expressa exatamente o oposto disso. E essa foi a experiência histórica do século $\mathrm{XX}$, que encontra sua raiz imediata nas ideologias que o dominaram e que provém, de modo mais imediato, do século XIX. É o que comenta Maritain na seguinte passagem:

Durante o século XIX existiu, a esse respeito, uma tremenda ambigüidade na ideologia democrática. Concepções e tendências, inspiradas por uma autêntica devoção ao povo e por uma verdadeira filosofia democrática, se confundiram com outros conceitos e outras tendências inspiradas por uma filosofia democrática espúria e por uma devoçáo errada, e até mesmo ditatorial em germe, pelo povo. Homens houve que acreditaram, como Jean-Jacques Rousseau o disse, que poderiam forçar o povo a ser livre. Declaro que esses homens foram traidores do povo, porque trataram o povo como se fosse um conjunto de crianças enfermas, ao passo que eles é que estavam clamando pelos direitos e pela liberdade do povo. Aqueles que não têm confiança no povo, mas, ao mesmo tempo, apelam para os mais altos sentimentos e para o sangue do povo, enganam e traem o povo. O primeiro axioma e preceito de uma democracia é a confiança no povo. Confiar no povo, respeitar o povo, confiar nele sobretudo enquanto o despertamos, isto é, enquanto nos colocamos ao serviço da sua dignidade humana ${ }^{21}$.

\subsection{O objeto da justiça: o direito}

Santo Tomás trata da virtude da justiça da questão 57 à 122 da segunda seção da segunda parte da Suma Teológica ${ }^{22}$. São mais de trezentos artigos que vão desde a justiça em geral a certas virtudes a ela conexas, como a religião e a epiqueia. $\mathrm{Na}$ última edição brasileira da $S_{u m a^{23}}$, esse tratado encontra-se integralmente no volume sexto.

$\mathrm{O}$ tratado aborda as questóes e os temas da justiça fundando-se na sua divisão ${ }^{24}$ segundo as suas partes subjetivas, integrantes e potenciais. As partes subjetivas são as espécies de justiça propriamente ditas, a saber, a justiça distributiva e a justiça comutativa; as partes integrantes são como que as "partes físicas” da justiça, ou seja, fazer o bem e evitar o mal a outro; as partes potenciais são as virtudes conexas à

\footnotetext{
${ }^{21}$ MARITAIN, Jacques. O homem e o Estado, p. 165.

${ }^{22}$ Santo Tomás trata do tema da justiça em outras obras, como: In decem libros Etilicorum Aristotelis ad Nicomachum expositio, especialmente no comentário ao livro V.

${ }^{23}$ Suma Teológica. São Paulo: Loyola, 2005.

${ }^{24}$ A lógica escolástica admite três tipos fundamentais de divisão de um todo: em suas partes integrais; em suas partes subjetivas; e em suas partes potenciais. A primeira é a divisão quantitativa, conforme o exemplo de no artigo que se segue, como quando se divide uma casa em paredes, teto e fundamento; na segunda; tem-se a divisão de gênero e espécies, que são as partes subjetivas de um todo; e, finalmente, as faculdades de colaboram para a atualizaçáo plena de alguma virtude ou potencialidade: "Respondeo dicendum quod triplex est pars, scilicet integralis, ut paries, tectum et fundamentum sunt partes domus; subiectiva, sicut bos et leo sunt partes animalis; et potentialis, sicut nutritivum et sensitivum sunt partes animae". TOMÁS DE AQUINO. Suma Teológica, II-II, q. 48, a. 1 c.
} 
justiça, que a potencializam. Essa parte central do tratado é precedida por uma abordagem geral da justiça em quatro questóes que versam sobre o direito, a justiça, a injustiça e o julgamento, respectivamente.

O tratado tomista inicia-se na questão 57 da Suma com a investigação sobre o objeto da justiça, que é o direito. Trata do direito em quatro artigos, que versam sobre o conceito de direito, sua fonte, sua divisão e sua relação com a justiça.

É próprio à justiça ordenar os atos que relativos a outros, de modo que haja certa igualdade entre os semelhantes. Diferentemente das outras virtudes que aperfeiçoam o homem em relação a si próprio, o que especifica a justiça é a relação correta com o outro. Essa igualdade ou correção entre semelhantes é o direito, o justo. Assim, é justa uma ação quando corresponde, segundo certa igualdade, a uma ação de outrem. E, por isso, a justiça tem por objeto o que é chamado de justo, e este é o direito.

A partir dessas consideraçōes iniciais, Santo Tomás divide, sempre seguindo Aristóteles, o direito entre natural e positivo. Como o que se está chamando de reto, de justo, é relativo ao homem, o fundamento metafísico do direito é a essência humana. E é a partir da conformidade com essa natureza que nasce o direito; e isso de dois modos: pela sua própria natureza, o direito natural; e em virtude de uma convenção, eis o direito positivo.

Embora o tratado da lei não pertença ao tratado que ora se expõe, o conceito de direito está intrinsecamente ligado ao de lei, seja à lei natural, seja à lei positiva. Por isso é importante ter presente que Tomás pensa a justiça consoante uma gradaçáo de participação na perfeita justiça divina. Assim, a lei, na definição de Santo Tomás, é "certa ordenação da razão em prol do bem comum, promulgada por quem tem o encargo da comunidade ${ }^{25}$ ". Esta definição tem aqui a função de estabelecer as relaçóes entre lei e direito. Dessa forma, é a lei que funda o direito, ao se tomar a lei no seu sentido mais amplo ou na seguinte ordem: lei eterna - direito divino - lei natural - direito natural - lei positiva - direito positivo, o que na verdade significa que o fundamento do direito é a lei que emana da autoridade divina e da autoridade humana, sempre como participação naquela.

Conclusão

À guisa de conclusão, algumas consequências podem aqui ser destacadas:

${ }_{25}$ TOMÁS DE AQUINO. Suma Teológica, I-II, q. 90, a. 4: "quaedam rationis ordinatio ad bonum commune, ab eo, curam communitatis habet, promulgata". 
1) A filosofia tomista não é uma filosofia entre as outras filosofias, pois ela goza de um duplo estatuto que lhe confere uma primazia diante de outras correntes: é filosofia cristã; e é a filosofia cristã que contém formalmente muitas das grandes conquistas positivas das filosofias modernas, especialmente das jurídicas.

2) O ser como experiência positiva como marca do tomismo e do pensamento cristáo. Esta experiência milenarmente teorizada pela filosofia cristá, especialmente por Santo Tomás, imprime-nos a certeza do valor da razáo e da verdade alcançada pelo cristianismo. É a descoberta do sentido do ser como participação que dá sentido a toda atividade moral, ao direito, à política. Porque somos felizes é que somos virtuosos...

3) A justiça não pode prescindir das virtudes que lhe são conexas, nem das outras virtudes cardeais e teologais. Por conseguinte, na ordem do amor, ela norteia-se pela esperança. E, como argumenta Tomás: O amor mais profundo nasce da esperança, que é desejo de plenitude: “...spes introducit ad caritatem, inquantum aliquis, sperans remunerari a Deo, accenditur ad amandum Deum et servandum praecepta eius." 26

26 Tomás de Aquino, Summa Theologiae, II-II, q. 17, a. 8: "...a esperança leva à caridade, na medida em que alguém, esperando ser recompensado por Deus, é estimulado a amá-lo e a obedecer seus mandamentos." 
Referência Bibliográfica

AGOSTINHO DE HIPONA. A Cidade de Deus. Petrópolis: Vozes, 1990.

ARISTÓTELES. Etica Nicomachea. Milão: Rusconi, 1993.

BOBBIO, Norberto. O positivismo jurídico. São Paulo: Ícone, 1995.

DEL VECCHIO, Giorgio. Liçôes de Filosofia do Direito. Coimbra, Arménio Amado, 1979.

DENZINGER, Henricus. Enchiridion Symbolorum. Friburgo da Brisg.: Herder, 1937. GEBHARDT, Carl (org.). Spinoza Opera. Heidelberg: Carl Winter, 1972.

FABRO, Cornelio. Introduzione a San Tommaso; La metafisica tomista \& il pensiero moderno. Milão: Ares, 1997.

. Riflessioni sulla libertà. Rimini: Maggioli, 1983.

GILSON, Étienne. Saint Thomas moraliste. Paris: J. Vrin, 1974.

GONZÁLEZ MORAL, Irenaeus. Philosophia Moralis. Santander: Sal Terrae, 1960.

HEGEL, Georg W. F. Fenomenologia do Espirito. Petrópolis: Vozes, 1992. . Lineas fundamentales de la filosofía del Derecho. Buenos Aires: Claridad, 1937.

KELSEN, Hans. Teoria geral do Direito e do Estado. São Paulo: Martins Fontes, 1995.

LYONS. La Somme de Saint Thomas d'Aquin résumée em tableaux synoptiques. Nice: Imprimerie Industrielle des Ateliers, 1901.

MARITAIN, Jacques. Problemas fundamentais de Filosofia Moral. Rio de Janeiro: AGIR, 1977.

. O homem e o Estado. Rio de Janeiro: AGIR, 1959.

OCKHAM, Guilherme de. Brevilóquio sobre o principado tirânico. Petrópolis: Vozes, 1988.

QUIDORT, Jean. Sobre o poder régio e papal. Petrópolis: Vozes, 1989.

REALE, Miguel. Filosofia do Direito. São Paulo: Saraiva, 1996.

ROMANO, Egídio. Sobre o poder eclesiástico. Petrópolis: Vozes, 1989.

SIGNORIELLO, Nuntio. Lexicon peripateticum philosophico-theologicum in quo scholasticorum distinctiones et effata explicantur. 5aed. Romae: Fridericus Pustet, 1931.

SPINOZA, Baruch. Tratado teológico-político. Lisboa: Imprensa Nacional, 1988.Ética. São Paulo: Nova Cultural, 1989.

TOMÁS DE AQUINO. Do governo dos príncipes; Do governo dos Judeus. São Paulo: Anchieta, 1946.

In decem libros Etilicorum Aristotelis ad Nicomachum expositio. Turim: Marietti, 1964.. In libros

politicorum expositio. Turim: Marietti, 1951.

Suma Teológica.. São Paulo: Loyola, 2005.

VALADIER, Paul. Maritain à contre-temps. Paris: Desclée de Brouwer, 2007. 